\title{
The effect of dietary arachidonic acid (ARA) on growth performance, fatty acid composition and expression of ARA metabolism-related genes in larval half-smooth tongue sole (Cynoglossus semilaevis)
}

\author{
Yuhui Yuan, Songlin Li, Kangsen Mai, Wei Xu, Yanjiao Zhang and Qinghui Ai* \\ Key Laboratory of Aquaculture Nutrition and Feed (Ministry of Agriculture) and Key Laboratory of Mariculture \\ (Ministry of Education), Ocean University of China, Qingdao 266003, People's Republic of China
}

(Submitted 24 June 2014 - Final revision received 2 January 2015 - Accepted 17 February 2015 - First published online 8 April 2015)

\section{Abstract}

The present study was conducted to investigate the effects of dietary arachidonic acid (ARA) on growth performance, fatty acid composition and ARA metabolism-related gene expression in larval half-smooth tongue sole (Cynoglossus semilaevis). Larvae (35 d after hatching, 54 (SEM 1) $\mathrm{mg}$ ) were fed diets with graded concentrations of ARA ( $0 \cdot 01,0 \cdot 39,0 \cdot 70,1 \cdot 07,1 \cdot 42$ and $2 \cdot 86 \%$ dry weight) five times per $\mathrm{d}$ to apparent satiation for $30 \mathrm{~d}$. Results showed that increased dietary ARA concentration caused a significant non-linear rise to a plateau in survival rate, final body weight and thermal growth coefficient, and the maximum values occurred with the $1.42 \%$ ARA treatment. As dietary ARA increased to 1.07 or $1.42 \%$, activities of trypsin, leucine aminopeptidase and alkaline phosphatase levels increased, but they decreased with higher ARA concentrations. The fatty acid composition of tongue sole larvae was almost well correlated with their dietary fatty acid profiles, and the EPA content of the larvae decreased with increasing dietary ARA. Meanwhile, the partial sequences of COX-1a (cyclo-oxygenase-1a), COX-1b (cyclo-oxygenase-1b), COX-2 (cyclo-oxygenase-2), 5-LOX (5-lipoxygenase) and CYP2J6-like (cytochrome P450 2J6-like) were also obtained. Both COX-2 and 5-LOX mRNA expression levels significantly increased to a plateau in an ' $\mathrm{L}$ '-shaped manner as dietary ARA increased to 1.07 or $1.42 \%$, but no significant differences were found in the gene expression of COX-1a, COX-1b or CYP2J6-like. These results suggest that $1 \cdot 07-1 \cdot 42 \%$ dietary ARA was beneficial to the growth performance of larval tongue sole, and the regulation of dietary ARA on the growth performance of larvae was probably involved in altering the mRNA expression of COX-2 and 5-LOX.

Key words: Arachidonic acid: Growth: Fatty acid composition: Digestive enzyme activity: Gene expression: Larvae: Cynoglossus semilaevis

The importance of arachidonic acid (20:4n-6, ARA), an $n-6$ long-chain PUFA, in fish nutrition has tended to be overlooked compared with EPA $(20: 5 n-3)$ and DHA $(22: 6 n-3)$ in the early research, because the latter two long-chain PUFA are more dominant than ARA in fish tissues ${ }^{(1,2)}$ and because the contribution of ARA to growth and survival is easily masked if other essential fatty acid levels are suboptimal ${ }^{(3)}$. However, in recent decades, it has been shown that ARA can be metabolised to form highly bioactive eicosanoids, such as PG, thromboxanes and leukotrienes (LT), which are very active even at low physiological concentrations and play critical roles in the regulation of several biological processes ${ }^{(4,5)}$. The potential benefits of optimal ARA nutrition to fish physiology and biochemistry have gradually become recognised ${ }^{(2)}$, and a number of studies have been conducted to investigate the effects of dietary ARA in various fish species ${ }^{(3,6-13)}$.
Previous studies have demonstrated that ARA is preferentially retained together with DHA during starvation in many fish species, which suggests that it has the same metabolic priority for conservation and relative importance as $\mathrm{DHA}^{(14,15)}$. Several studies have also revealed that dietary ARA contributes to enhanced survival and growth rates $^{(7,9,10,16)}$ and influences the tissue fatty acid profile ${ }^{(12,13,17)}$ in a variety of teleosts. In particular, ARA has been reported to play an important role in regulating the reproductive performance of brood stock ${ }^{(18-22)}$ and the stress resistance of larval fish $^{(1,6,8,11,23-25)}$. Moreover, the effects of ARA on a range of physiological processes in marine fish, such as metamorphosis $^{(26,27)}$, pigmentation ${ }^{(9,28,29)}$ and immune response ${ }^{(3,30)}$, have also been investigated by different research groups. However, no study to date has focused on the metabolic mechanism of ARA in marine fish.

Abbreviations: ALP, alkaline phosphatase; ARA, arachidonic acid; BBM, brush border membrane; cDNA, complementary DNA; COX, cyclo-oxygenase; CYP, cytochrome P450; EET, epoxyeicosatrienoic acid; IS, intestinal segment; LAP, leucine aminopeptidase; LOX, lipoxygenase; LT, leukotriene; PS, pancreatic segment.

*Corresponding author: Q. Ai, fax: +86532 82031943, email qhai@ouc.edu.cn; aiqinghui@163.com 
In mammals, the metabolism of ARA and the function of ARA metabolites have been widely investigated ${ }^{(31)}$. Membrane-bound endogenous fatty acid ARA can be released from membranes by phospholipases and then metabolised to biologically active compounds by cyclo-oxygenases (COX), lipoxygenases (LOX) and cytochrome P450 (CYP) enzymes $^{(4,31,32)}$. ARA is mainly metabolised to three distinct classes of metabolites in animal models and humans: COX produces PG and thromboxanes; LOX produces hydroperoxyeicosatetraenoic acids, LT and lipoxins; and the CYP enzyme, an NADPH-dependent epoxygenase, produces epoxyeicosatrienoic acids (EET) ${ }^{(31)}$. These metabolites have been shown to play important functional roles in a variety of fundamental biological processes, such as cellular proliferation, inflammation, vascular and bronchial smooth muscle tone, peptide hormone secretion and intracellular signalling ${ }^{(5,33-35)}$. In fish species, investigations involved in ARA metabolism have generally focused on the COX (especially the COX-2) pathway $^{(11,23,36)}$, and few studies have been conducted on the other metabolic pathways of ARA.

COX-1 and COX-2 are the key enzymes responsible for prostanoid production from ARA ${ }^{(37)}$. Under many circumstances, the COX-1 enzyme is produced constitutively, whereas COX-2 is inducible ${ }^{(38)}$. The constitutively expressed COX-1 is responsible for basal synthesis and, upon stimulation, for immediate PG synthesis, which also occurs at high ARA concentrations ${ }^{(39)}$. COX-2 is induced by a variety of stimuli, such as cytokines and growth factors, and it is primarily involved in the regulation of inflammatory responses as well as cell differentiation and proliferation ${ }^{(39,40)}$. 5 -LOX is a member of the family of LOX that also includes 12- and 15-LOX ${ }^{(41)}$. It catalyses ARA to form 5-hydroperoxyeicosatetraenoic acid and subsequently metabolises to $\mathrm{LT}^{(4,41)}$. 5-LOX is the rate-limiting enzyme in LT synthesis $^{(42)}$. CYP enzymes comprise a highly diverse superfamily found in all domains of life, and one of the important physiological roles of CYP enzymes is that they are involved in the metabolism of ARA ${ }^{(43)}$. CYP monooxygenases catalyse the epoxidation of ARA to form $\operatorname{EET}^{(44,45)}$. EET are endogenous constituents of numerous tissues and possess a variety of potent biological activities, such as controlling peptide hormone secretion in the pancreas, pituitary gland and hypothalamus and regulating vascular tone in the intestine and brain ${ }^{(46)}$. In vertebrates, the CYP4A, CYP2C and CYP2J subfamilies were generally believed to be the major enzymes involved in EET synthesis from ARA ${ }^{(47,48)}$. However, no study has reported the effects of dietary ARA concentrations on the gene expression of COX-1, 5-LOX and CYP enzymes in marine fish, and the effect of different dietary ARA concentrations on COX-2 mRNA expression is also rarely reported ${ }^{(11)}$.

Half-smooth tongue sole (Cynoglossus semilaevis) is a high-value marine flatfish with a notably lethargic browsing feeding habit ${ }^{(50)}$, and it is extensively exploited in northern China ${ }^{(49)}$. A few studies have been reported on the nutrition of tongue sole ${ }^{(50-53)}$, but no information is available about its ARA nutrition. ARA can be converted to a number of compounds, including PG, thromboxanes, hydroxyeicosatetraenoic acids and $\mathrm{LT}^{(31)}$, which are very active even at low physiological concentrations and play an important role during larval development ${ }^{(7)}$. It has been demonstrated that bone development and composition at the larval stage are highly sensitive to the dietary concentration of ARA ${ }^{(54)}$. In addition, fish larvae possess a high growth rate ${ }^{(55)}$, which indicates that metabolism in this stage is active; thus, tongue sole larvae appear to be more sensitive to ARA nutrition than juvenile tongue sole are.

Hence, the present study was designed to determine the effects of dietary ARA concentrations on growth performance, the activities of digestive enzymes and the fatty acid profiles of larval tongue sole. The responses of some ARA metabolismrelated gene expression to dietary ARA concentrations were also investigated.

\section{Materials and methods}

\section{Feed ingredients and diet formulation}

A total of six diets were formulated to contain approximately $56 \%$ crude protein and $14 \%$ lipids, a combination that has been shown to be sufficient to support the optimal growth of larval tongue sole (Table 1). ARA-enriched oil (ARA content: $53.78 \%$ of total fatty acid in the form of ARA-methylester; Jiangsu Tiankai Biotechnology Company Limited) was supplemented to the basal diet separately as a substitute for palmitin (palmitic acid content: $97.6 \%$ of total fatty acid in the form of methylester; Shanghai Zhixin Chemical Company Limited) in order to create six diets that contained ARA levels of $0.01,0.39,0.70,1 \cdot 07,1.42$ and $2 \cdot 86 \%$ dry weight, respectively. DHA-enriched oil (DHA content: $40 \cdot 64 \%$ of total fatty acid in the form of DHA-methylester; Jiangsu Tiankai Biotechnology Company Limited) and EPA-enriched oil (45.9\% EPA and $23.8 \%$ DHA of total fatty acid, both in the form of TAG; Hebei Haiyuan Health Biological Science and Technology Company Limited) were added to keep the DHA:EPA ratio at approximately 2.0 (Table 2). Defatted fishmeal, krill meal, squid meal and hydrolysed fishmeal, together with casein, were chosen as the primary protein sources.

The primary ingredients were ground into a fine powder through $75 \mu \mathrm{m}$ mesh. After that, the ingredients for all of the diets were blended manually, and then the oil mixtures (ARAenriched oil, DHA-enriched oil, EPA-enriched oil, palmitin and lecithin) were added to each diet and mixed thoroughly with the other ingredients. Water was incorporated to produce a stiff dough. Pellets were created with an automatic pelletmaking machine (Weihai) and dried for about $8 \mathrm{~h}$ in a ventilated oven at $45^{\circ} \mathrm{C}$. After drying, the pellets were broken and sieved to obtain two particle sizes: $180-250 \mu \mathrm{m}$ for the fish larvae between 35 and $50 \mathrm{~d}$ after hatching and $250-420 \mu \mathrm{m}$ for the larval fish between 50 and $65 \mathrm{~d}$ after hatching. All of the formulated diets were packed in separate silver bags and stored at $-20^{\circ} \mathrm{C}$ until they were used.

\section{Experimental procedure}

The larvae used in the present study were obtained and reared at the hatchery of the Haiyang Seafood Company in Yantai (Shandong, China). Before the experiment, the initial wet 
Table 1. Formulation and proximate analysis of the experimental diets (\% dry weight)

\begin{tabular}{|c|c|c|c|c|c|c|}
\hline \multirow[b]{2}{*}{ Ingredients } & \multicolumn{6}{|c|}{ Dietary ARA content (\% dry weight) } \\
\hline & 0.01 & 0.39 & 0.70 & 1.07 & 1.42 & $2 \cdot 86$ \\
\hline Defatted fishmeal ${ }^{*}$ & 33.0 & 33.0 & 33.0 & 33.0 & 33.0 & 33.0 \\
\hline Casein $^{\star}$ & $10 \cdot 0$ & 10.0 & $10 \cdot 0$ & $10 \cdot 0$ & 10.0 & $10 \cdot 0$ \\
\hline Krill meal† & 11.0 & $11 \cdot 0$ & 11.0 & $11 \cdot 0$ & $11 \cdot 0$ & 11.0 \\
\hline Squid meal & $10 \cdot 0$ & $10 \cdot 0$ & $10 \cdot 0$ & $10 \cdot 0$ & $10 \cdot 0$ & $10 \cdot 0$ \\
\hline Hydrolysed fishmealt & 8.00 & 8.00 & 8.00 & 8.00 & 8.00 & 8.00 \\
\hline LT-yeast & 2.00 & 2.00 & 2.00 & $2 \cdot 00$ & $2 \cdot 00$ & $2 \cdot 00$ \\
\hline Soya lecithin & 4.00 & 4.00 & 4.00 & 4.00 & 4.00 & 4.00 \\
\hline DHA-enriched oilł & 2.50 & 2.50 & 2.50 & $2 \cdot 50$ & 2.50 & $2 \cdot 50$ \\
\hline EPA-enriched oilł & $1 \cdot 10$ & $1 \cdot 10$ & $1 \cdot 10$ & $1 \cdot 10$ & $1 \cdot 10$ & $1 \cdot 10$ \\
\hline ARA-enriched oilł & 0.00 & 0.75 & 1.50 & $2 \cdot 25$ & 3.00 & $6 \cdot 00$ \\
\hline Palmitin $\ddagger$ & 6.00 & 5.25 & 4.50 & 3.75 & 3.00 & 0.00 \\
\hline$\alpha$-Starch & $5 \cdot 50$ & $5 \cdot 50$ & 5.50 & $5 \cdot 50$ & 5.50 & $5 \cdot 50$ \\
\hline Sodium alginate & 1.50 & 1.50 & 1.50 & 1.50 & 1.50 & 1.50 \\
\hline Vitamin premix§ & 1.50 & 1.50 & 1.50 & 1.50 & 1.50 & 1.50 \\
\hline Mineral premix $\|$ & 1.50 & 1.50 & 1.50 & 1.50 & 1.50 & 1.50 \\
\hline Attractant $\emptyset$ & 2.00 & 2.00 & 2.00 & $2 \cdot 00$ & $2 \cdot 00$ & $2 \cdot 00$ \\
\hline Antioxidant** & 0.10 & $0 \cdot 10$ & 0.10 & $0 \cdot 10$ & $0 \cdot 10$ & $0 \cdot 10$ \\
\hline Choline chloride & 0.20 & 0.20 & 0.20 & 0.20 & 0.20 & 0.20 \\
\hline Mould inhibitortt & $0 \cdot 10$ & 0.10 & 0.10 & 0.10 & 0.10 & 0.10 \\
\hline \multicolumn{7}{|c|}{ Proximate composition ( $n 3$ ) } \\
\hline Crude protein (\%) & $56 \cdot 3$ & 55.9 & $56 \cdot 1$ & $56 \cdot 1$ & $56 \cdot 2$ & 55.9 \\
\hline Crude lipid (\%) & 13.9 & $14 \cdot 0$ & $14 \cdot 0$ & $14 \cdot 0$ & $14 \cdot 1$ & $14 \cdot 1$ \\
\hline ARA (\%) & 0.01 & 0.39 & 0.70 & 1.07 & 1.42 & 2.86 \\
\hline
\end{tabular}

ARA, arachidonic acid.

* Defatted fishmeal: crude protein $77.81 \%$ DM crude lipid $2.88 \%$ DM (white fishmeal were defatted with ethanol (fishmeal-ethanol 1:2, w:v) at $37^{\circ} \mathrm{C}$ three times); casein: crude protein $92.34 \%$ DM, crude lipid 0.89\% DM (all supplied by Qingdao Great Seven Bio-Tech Company Limited).

† Krill meal: crude protein $52.99 \%$ DM, crude lipid $12.95 \%$ DM (Shandong Keruier Biological Products Company Limited); squid meal: crude protein $62.72 \%$ DM, crude lipid 3.5\% DM; hydrolysed fishmeal: crude protein $75.98 \%$ DM, crude lipid $1.34 \%$ DM (Zhejiang Jinhaiyun Biology Company Limited).

¥DHA-enriched oil: DHA content $40.64 \%$ of total fatty acid (TFA) in the form of DHA-methylester (Jiangsu Tiankai Biotechnology Company Limited); EPA-enriched oil: EPA content $45.9 \%$ of TFA, DHA content $23.8 \%$ of TFA, both in the form of TAG (Hebei Haiyuan Health Biological Science and Technology Company Limited); ARA-enriched oil: ARA content $53.78 \%$ of TFA in the form of ARA-methylester (Jiangsu Tiankai Biotechnology Company Limited); palmitin: palmitic acid (16:0) content $97.60 \%$ of TFA in the form of methylester (Shanghai Zhixin Chemical Company Limited).

$\S$ Vitamin premix (IU or $\mathrm{g} / \mathrm{kg}$ vitamin premix): retinal palmitate, $3000000 \mathrm{IU}$; cholecalciferol, $1200000 \mathrm{IU}$; DL- $\alpha$-tocopherol acetate, $40.0 \mathrm{~g}$; menadione, $8.0 \mathrm{~g}$; thiamin- $\mathrm{HCl}, 5.0 \mathrm{~g}$; riboflavin, $5.0 \mathrm{~g}$; D-calcium pantothenate, $16.0 \mathrm{~g}$; pyridoxine-HCl, $4.0 \mathrm{~g} ;$ meso-inositol, $200.0 \mathrm{~g}$; D-biotin, $8.0 \mathrm{~g}$; folic acid, $1.5 \mathrm{~g}$; para-aminobenzoic acid, $5.0 \mathrm{~g}$; niacin, $20.0 \mathrm{~g}$; cyanocobalamin, $0.01 \mathrm{~g}$; ascorbyl polyphosphate (containing $25 \%$ ascorbic acid), $100.0 \mathrm{~g}$

II Mineral premix (g/kg): $\mathrm{Ca}\left(\mathrm{H}_{2} \mathrm{PO}_{4}\right)_{2} \cdot \mathrm{H}_{2} \mathrm{O}, 675 \cdot 0 ; \mathrm{CoSO}_{4} \cdot 4 \mathrm{H}_{2} \mathrm{O}, 0.15 ; \mathrm{CuSO}_{4} \cdot 5 \mathrm{H}_{2} \mathrm{O}, 5 \cdot 0 ; \mathrm{FeSO}_{4} \cdot 7 \mathrm{H}_{2} \mathrm{O}, 50 \cdot 0 ; \mathrm{KCl}, 50 \cdot 0 ; \mathrm{KI}, 0 \cdot 1 ; \mathrm{MgSO}_{4} \cdot 2 \mathrm{H}_{2} \mathrm{O}$ 101.7; $\mathrm{MnSO}_{4} \cdot 4 \mathrm{H}_{2} \mathrm{O}, 18 \cdot 0 ; \mathrm{NaCl}, 80 \cdot 0 ; \mathrm{Na}_{2} \mathrm{SeO}_{3} \cdot \mathrm{H}_{2} \mathrm{O}, 0 \cdot 05 ; \mathrm{ZnSO}_{4} \cdot 7 \mathrm{H}_{2} \mathrm{O}, 20 \cdot 0$.

I Attractant (g/100 g): betaine, 50; glycine, 15; alanine, 10; argine, 10; taurine, 10; inosine-5'-monophosphoric acid, 5 .

${ }^{* *}$ Antioxidant: ethoxyquin.

†† Mould inhibitor: $50 \%$ calcium propionic acid, $50 \%$ fumaric acid

body weights of 100 randomly sampled larvae were measured. With a stocking destiny of 180 individuals per tank, a total of 3240 larvae (35 d after hatching, 54 (sem 1) mg) were randomly distributed into eighteen tanks with flat bottoms $(65 \times 65 \times 90 \mathrm{~cm})$. Seawater was continuously pumped from the coast adjacent to the experiment station and passed through sand filters into each tank. About $200-400 \%$ of the water volume was renewed daily, and each tank had an air stone. The feeding trial lasted for $30 \mathrm{~d}$. At the beginning, the fish were fasted for $24 \mathrm{~h}$, and each diet was randomly assigned to three groups of fish. Enriched Artemia nauplii and a microdiet were used alternately to wean the larvae for $3 \mathrm{~d}$ before the formal experiment began. Fish were manually fed with the corresponding experimental diets to apparent satiation five times daily (at 06.00, 9.00, 15.00, 18.00 and 21.00 hours). During the rearing period, water temperature was kept at $24 \pm 1^{\circ} \mathrm{C}$, pH was $8 \cdot 0 \pm 0 \cdot 2$ and salinity was $30 \pm 3 \%$.
The surface water was skimmed with a polyvinyl chloride (PVC) tube to remove the suspended waste. Also, accumulations of feed and faeces at the tank bottoms were siphoned $40 \mathrm{~min}$ after feeding. At the termination of the experiment, thirty fish were randomly sampled from each tank to determine wet body weight. All of the fish were deprived of food for $24 \mathrm{~h}$ before sampling. Survival was determined by counting the individuals remaining in each tank. All of the larvae were anaesthetised with eugenol (1:10 000) (Shanghai Reagent) and rinsed in distilled water before further treatment; larvae that were collected for further assays were immediately frozen in liquid $\mathrm{N}_{2}$ and then stored at $-80^{\circ} \mathrm{C}$.

\section{Biochemical analysis}

The chemical composition of the diets was determined according to the standard procedures ${ }^{(56)}$. Samples of the 
Table 2. Fatty acid composition of the experimental diets (\% total fatty acids)*

\begin{tabular}{|c|c|c|c|c|c|c|}
\hline \multirow[b]{2}{*}{ Fatty acid } & \multicolumn{6}{|c|}{ Dietary ARA content (\% DM) } \\
\hline & 0.01 & 0.39 & 0.70 & 1.07 & 1.42 & $2 \cdot 86$ \\
\hline $14: 0$ & $2 \cdot 48$ & $2 \cdot 30$ & $2 \cdot 28$ & 2.37 & 2.42 & $2 \cdot 32$ \\
\hline $16: 0$ & $51 \cdot 0$ & 48.5 & 43.4 & $36 \cdot 3$ & $32 \cdot 9$ & $16 \cdot 8$ \\
\hline $18: 0$ & 0.04 & 0.06 & 0.05 & 0.06 & 0.07 & 0.06 \\
\hline $20: 0$ & 1.95 & 1.87 & 1.93 & 1.96 & 2.03 & $2 \cdot 18$ \\
\hline$\Sigma$ SFA & $55 \cdot 4$ & $52 \cdot 7$ & $47 \cdot 7$ & $40 \cdot 7$ & 37.4 & 21.4 \\
\hline $16: 1$ & 0.75 & 0.69 & 0.67 & 3.05 & 1.50 & 2.53 \\
\hline $18: 1 n-9$ & 1.56 & 1.73 & 1.96 & $2 \cdot 19$ & $2 \cdot 73$ & 3.26 \\
\hline $18: 1 n-7$ & 8.50 & 8.53 & 8.84 & 9.25 & $9 \cdot 34$ & $11 \cdot 0$ \\
\hline ¿MUFA & $10 \cdot 8$ & $11 \cdot 0$ & 11.5 & 14.5 & 13.6 & $16 \cdot 8$ \\
\hline $18: 2 n-6$ & $10 \cdot 0$ & 9.87 & $10 \cdot 3$ & $10 \cdot 5$ & $10 \cdot 5$ & $11 \cdot 6$ \\
\hline $20: 4 n-6$ (ARA) & $0 \cdot 13$ & $2 \cdot 63$ & 4.67 & 6.74 & $9 \cdot 16$ & $16 \cdot 9$ \\
\hline$\sum n-6$ PUFA & $10 \cdot 1$ & 12.5 & $15 \cdot 0$ & $17 \cdot 2$ & $19 \cdot 6$ & 28.5 \\
\hline $18: 3 n-3$ & 1.40 & 1.37 & 1.42 & 1.42 & 1.39 & 1.45 \\
\hline $20: 5 n-3$ (EPA) & $5 \cdot 36$ & $5 \cdot 14$ & $5 \cdot 24$ & $5 \cdot 17$ & 5.40 & 5.22 \\
\hline $22: 6 n-3(\mathrm{DHA})$ & $10 \cdot 2$ & $10 \cdot 2$ & $11 \cdot 2$ & $10 \cdot 7$ & $11 \cdot 8$ & $11 \cdot 8$ \\
\hline$\sum n-3$ PUFA & $16 \cdot 9$ & $16 \cdot 7$ & $17 \cdot 9$ & $17 \cdot 3$ & 18.5 & 18.5 \\
\hline$\sum n-3: \Sigma n-6$ PUFA & 1.67 & 1.34 & 1.19 & 1.00 & 0.94 & 0.65 \\
\hline DHA:EPA & 1.90 & 1.99 & $2 \cdot 15$ & $2 \cdot 07$ & $2 \cdot 18$ & $2 \cdot 26$ \\
\hline EPA:ARA & $42 \cdot 7$ & 1.95 & 1.12 & 0.77 & 0.59 & 0.31 \\
\hline
\end{tabular}

ARA, arachidonic acid.

* Some fatty acids, of which the contents were minor, in trace amounts or not detected (such as $22: 0,24: 0,14: 1,20: 1 n-9,22: 1 n-11,20: 2 n-6,20: 3 n-6$ and $22: 5 n-3)$, are not listed in Table 2.

diets were dried to a constant weight at $105^{\circ} \mathrm{C}$ to determine their DM content. Crude protein was determined by digestion using the Kjeldahl method $(\mathrm{N} \times 6.25)$; crude lipid was measured by diethyl ether extraction using the Soxhlet method.

The fatty acid profiles were analysed using the procedure described by Metcalfe et al. ${ }^{(57)}$ with some modification ${ }^{(58)}$. Fatty acid methyl esters were separated and quantified using HP6890 gas chromatograph equipment (Agilents Technologies, Inc.) with a fused silica capillary column (007-CW; Hewlett Packard) and a flame ionisation detector. The column temperature was programmed to rise from 150 to $200^{\circ} \mathrm{C}$ at a rate of $15^{\circ} \mathrm{C} / \mathrm{min}$, from 200 to $270^{\circ} \mathrm{C}$ at a rate of $2^{\circ} \mathrm{C} / \mathrm{min}$ and then kept steady for $10 \mathrm{~min}$. The injector and detector temperature was $270^{\circ} \mathrm{C}$. A Supelco 37 Component FAME Mix (NU-CHEK) and an HPCore ChemStation workstation were used to identify and quantify each fatty acid after separation using GC.

\section{Digestive enzymatic assays}

Enzymatic assays were determined on the pancreatic segments (PS), intestinal segments (IS) and brush border membranes
(BBM) of the digestive tracts. The larvae were dissected on a glass plate maintained at $0^{\circ} \mathrm{C}$ according to the methods for sole described previously by Ribeiro et al ${ }^{(59)}$. Digestive tracts were separated at the junction of the oesophagus and the pyloric sphincter to obtain the PS and IS. Dissected samples were refrozen at $-80^{\circ} \mathrm{C}$ for the enzymatic assays. Purified BBM from the IS homogenate was obtained following the method developed for intestinal scrapings by Crane et $a l .{ }^{(60)}$ and Zambonino Infante et al. ${ }^{(61)}$. Trypsin activity and amylase activity were assayed using Na-benzoyl-DL-arginine- $p$ nitroanilide $(\mathrm{B}-4875)^{(62)}$ and starch (S-9765) ${ }^{(63)}$ as substrates, respectively. In both the PS and the IS, lipase activities were assayed using polyvinyl alcohol (PVA)-olive oil emulsion as the substrate according to the method described by Brockman ${ }^{(64)}$. Alkaline phosphatase (ALP) activity was measured using $p$-nitrophenylphosphate (106850; Merck) and $\mathrm{MgCl}_{2}$ as the substrates ${ }^{(65)}$, and leucine aminopeptidase (LAP) activity was measured using leucine-p-nitroanilide (L-9125; Sigma) as the substrate ${ }^{(66)}$. Protein concentration was determined according to the method described by Bradford ${ }^{(67)}$ using bovine serum albumin (A-2153; Sigma) as a standard. Enzyme activities are expressed as specific activity ( $\mathrm{mU} \mathrm{mg} /$ protein or $\mathrm{U} \mathrm{mg} /$ protein).

A single unit of enzyme activity was defined as the amount of enzyme that hydrolyses $1 \mu \mathrm{mol}$ of substrate per min at $37^{\circ} \mathrm{C}$ for ALP and LAP and at $25^{\circ} \mathrm{C}$ for trypsin. Amylase activity was expressed as the equivalent enzyme activity required to hydrolyse $1 \mathrm{mg}$ of starch in $30 \mathrm{~min}$ at $37^{\circ} \mathrm{C}$. A single unit of lipase activity was defined as $1 \mu \mathrm{mol}$ of fatty acid released by the hydrolysing lipid in $1 \mathrm{~min}$ at $37^{\circ} \mathrm{C}$.

\section{RNA extraction and reverse transcription}

Total RNA was extracted from larval visceral mass using Trizol Reagent (Invitrogen) according to the manufacturer's instructions and electrophoresed on a $1.2 \%$ denaturing agarose gel to test the integrity. The purity and concentration of total RNA were determined by NanoDrop ${ }^{\circledR}$ ND-1000. The absorption ratios $(260: 280 \mathrm{~nm})$ for all of the samples were approximately 2.00. Then first-strand complementary DNA (cDNA) was synthesised using a PrimeScript ${ }^{\mathrm{TM}}$ RT Reagent Kit (Takara) according to the manufacturer's instructions. The resulting product was used as a template for PCR amplification.

\section{Partial cloning of arachidonic acid metabolism-related genes}

In order to obtain fragments of the $C O X-1, C O X-2,5-L O X$ and CYP2J genes, four pairs of degenerate PCR primers (Table 3)

Table 3. PCR primers for arachidonic acid metabolism-related gene cloning of larval tongue sole (Cynoglossus semilaevis)

\begin{tabular}{lllrr}
\hline Target gene & Forward primer $\left(5^{\prime}-3^{\prime}\right)$ & Reverse primer $\left(5^{\prime}-3^{\prime}\right)$ & Product size $(\mathrm{bp})$ & Annealing temperature $\left({ }^{\circ} \mathrm{C}\right)$ \\
\hline COX-1 & TCACCCACCAGTT(C/T)T(C/T)TA & CCTGTA(C/T)TC(A/G)TTGAAGGG & 780 & 48.1 \\
COX-2 & CA(C/T)TTCACCCACCAGTTCTT & GTGCT(G/T/C)GG(C/T)TTCCAGTAC & 1040 & $54 \cdot 2$ \\
5-LOX & TG(G/A/C)A(A/G)CACTGGAA(A/G)GAGG & ACCAGTCA(A/T)ACTGTCC(A/G)AAG & 1010 & 50.3 \\
CYP2J & GGGAA(C/T)(A/C)TTTTTAGCCTG & TGACAGCATTGGTGTAGGG & 870 & $54 \cdot 3$ \\
\hline
\end{tabular}

COX-1, cyclo-oxygenase 1; COX-2, cyclo-oxygenase 2; 5-LOX, 5-lipoxygenase; CYP2J, cytochrome P450 2J. 
Table 4. Real-time quantitative PCR primers for arachidonic acid metabolism-related genes and $\beta-2$ microglobulin of larval tongue sole (Cynoglossus semilaevis)

\begin{tabular}{|c|c|c|c|}
\hline Gene & Forward sequence $\left(5^{\prime}-3^{\prime}\right)$ & Reverse sequence $\left(5^{\prime}-3^{\prime}\right)$ & GenBank number \\
\hline $\operatorname{cox}-1 a$ & AGCATCAATGTCACCGTAGAGC & TCCAATGAAGTTGTCCTGAGAGTG & KF533723 \\
\hline$C O X-1 b$ & TCCGAACACTTCCTGACCAATAG & GCTCCAACTTAGGCTTCACAAAG & KF533724 \\
\hline $\operatorname{cox}-2$ & CCAAACCACAAGGCTCATTCTG & GTGTTAAACTCTGAGGCGATGC & KF533725 \\
\hline $5-L O X$ & ACACGACGCAGTACATAGCAG & TGGTAATGGAAGTCAGCCGAAC & KF533726 \\
\hline CYP2J6-like & GCCAAAGGTGCGTAGGGTAG & GACAAAGCCGTGTTTCTGACTG & KJ578726 \\
\hline$\beta-2$ Microglobulin & TTGGCTCGTGTTCGTCGTTC & TCAGGGTGTTGGGCTTGTTG & FJ965561 \\
\hline
\end{tabular}

were designed by Primer Premier 5.0 in highly conserved regions on the basis of available sequences in Genbank and were synthesised by Biosune Biotech. PCR was performed on a volume of $25 \mu \mathrm{l}$ that contained $1 \mu \mathrm{l}$ each of primer $(10 \mu \mathrm{M})$ and cDNA, $9.5 \mu \mathrm{l}$ of sterilised double-distilled water and $12.5 \mu \mathrm{l}$ of Taq Mix (TransGen Biotech). The PCR programme was carried out by Eppendorf Mastercycler Gradient (Eppendorf), and the PCR conditions were: 2 min at $94^{\circ} \mathrm{C}$; thirty-five cycles of $30 \mathrm{~s}$ at $94^{\circ} \mathrm{C}, 30 \mathrm{~s}$ at the annealing temperature (Table 3 ) and $40 \mathrm{~s}$ (changed according to the length of the target gene) at $72^{\circ} \mathrm{C}$; and then another $10 \mathrm{~min}$ at $72^{\circ} \mathrm{C}$. The amplification products were separated by electrophoresis on a $1.5 \%$ agarose gel according to their length, and then the target band was ligated into the pEASY-T1 vector (TransGen Biotech). A total of $2 \mu \mathrm{l}$ of each ligation reaction were transformed into the competent cells of Escherichia coli TOP10 and then plated on Lysogeny broth (LB) agar plates. The positive clones in each PCR fragment were sequenced in Sangon Biotech. Sequence alignment and analysis were conducted using the BLAST sequence analysis service of the National Center for Biotechnology Information (http://blast.ncbi.nlm. nih.gov/). Multiple alignments of the target genes were performed with the ClustalW Multiple Alignment Program (http://www.ebi.ac.uk/Tools/msa/clustalo/).

\section{Real-time quantitative PCR}

The quantitative PCR primer pairs (Table 4) were designed by Primer Premier 5.0 based on the obtained nucleotide sequences of COX-1a (GenBank accession no. KF533723), COX-1b (GenBank accession no. KF533724), COX-2 (GenBank accession no. KF533725), 5-LOX (GenBank accession no. KF533726), CYP2J6-like (GenBank accession no. $\mathrm{KJ} 578726$ ) and $\beta-2$ microglobulin (GenBank accession no. FJ965561) in tongue sole. The mRNA expression levels were normalised to $\beta-2$ microglobulin. Real-time quantitative PCR was carried out in a quantitative thermal cycler (Mastercycler ep realplex; Eppendorf). The amplification was performed on a total volume of $25 \mu \mathrm{l}$ that contained $1 \mu \mathrm{l}$ of primer $(10 \mu \mathrm{M}), 1 \mu \mathrm{l}$ of the diluted first-strand cDNA product, $12 \cdot 5 \mu \mathrm{l}$ of $2 \times$ SYBR $^{\circledR}$ Premix Ex Taq $^{\text {TM }}$ and $9.5 \mu$ of sterilised double-distilled water. The quantitative PCR programme was as follows: $95^{\circ} \mathrm{C}$ for $2 \mathrm{~min}$, followed by forty cycles of $10 \mathrm{~s}$ at $95^{\circ} \mathrm{C}, 10 \mathrm{~s}$ at $58^{\circ} \mathrm{C}$ and $20 \mathrm{~s}$ at $72^{\circ} \mathrm{C}$. At the end of each PCR, melting curve analysis was performed to confirm that only one PCR product was present in these reactions. Standard curves were made with six different dilutions (in triplicate) of the cDNA samples, and amplification efficiency was analysed according to the following equation: $E=10^{(-1 / \text { slope })}-1^{(68)}$. The primers' amplification efficiencies were $0.940\left(R^{2} 0.998\right)$, $0.960\left(R^{2} 0.991\right), 0.978\left(R^{2} 0.998\right), 0.951\left(R^{2} 0.987\right), 0.954$ $\left(R^{2} 0.998\right)$ and $0.948\left(R^{2} 0.995\right)$ for COX-1a, COX-1b, $C O X-2,5-L O X, C Y P 2 J 6-l i k e$ and $\beta-2$ microglobulin, respectively. Plots of the $\log$ DNA dilution $v . \Delta C_{\mathrm{t}}\left(C_{\mathrm{t}, \text { target gene }}-\right.$ $\left.C_{\mathrm{t}, \beta \text {-2microglobulin }}\right)$ were made, and the slopes were calculated. The absolute values of the slopes were all close to zero, which indicates that the efficiencies of the target and reference genes were similar, and the expression levels of the target genes were calculated following the $2^{-\Delta \Delta C_{t}}$ method described by Livak \& Schmittgen ${ }^{(68)}$.

\section{Calculations and statistical analysis}

The following variables were calculated:

Thermal growth coefficient (TGC, ng dry weight $/{ }^{\circ} \mathrm{C} \times \mathrm{d}$ ) $=\left(W_{\mathrm{f}}^{1 / 3}-W_{\mathrm{i}}^{1 / 3}\right) \times 1000 / \Sigma(t \times$ feeding days $)$,

where $\Sigma(t \times$ feeding days $)$ was the sum of the water temperatures $\left({ }^{\circ} \mathrm{C}\right)$ for every feeding day in the experiment.

$$
\text { Survival rate }(\mathrm{SR}, \%)=100 \times N_{\mathrm{ft}} / N_{\mathrm{fi}},
$$

where $N_{\mathrm{fi}}$ and $N_{\mathrm{ft}}$ were the initial and final fish number in the experiment, respectively.

All of the statistical evaluations were performed using SPSS version 19.0 (SPSS, Inc.). Polynomial contrasts (linear, quadratic and cubic) were used to test the effect of the dietary ARA concentrations on the various variables measured. The level of significance was set at $P<0.05$, and the results are presented as mean values with pooled standard errors.

\section{Results}

\section{Survival and growth}

An increase in dietary ARA concentration caused a non-linear rise to a plateau in SR, final body weight and TGC. When the dietary ARA concentration increased from 0.01 to $1.42 \%$, SR increased from 20.91 to $30.53 \%$, and larvae that were fed the diet with $1.42 \%$ ARA had the highest SR as compared to the other treatments. Also, in the $1.42 \%$ dietary ARA treatment, final body weight obtained the highest value as compared to the other treatments. The TGC of larvae fed the 
Table 5. Growth response and survival rates of larval tongue sole fed diets with graded concentrations of arachidonic acid (ARA) (Mean values with their pooled standard errors) ${ }^{\star}$

\begin{tabular}{|c|c|c|c|c|c|c|c|c|c|c|}
\hline \multirow[b]{2}{*}{ Growth response } & \multicolumn{6}{|c|}{ Dietary ARA content (\% DM) } & \multirow[b]{2}{*}{ Pooled SEM } & \multicolumn{3}{|c|}{ Polynomial contrasts } \\
\hline & 0.01 & 0.39 & 0.70 & 1.07 & 1.42 & $2 \cdot 86$ & & Linear & Quadratic & Cubic \\
\hline Initial body weight (mg) & $54 \cdot 0$ & $54 \cdot 0$ & $54 \cdot 0$ & $54 \cdot 0$ & $54 \cdot 0$ & $54 \cdot 0$ & & & & \\
\hline Final body weight $(\mathrm{g})$ & 0.14 & 0.16 & 0.19 & 0.18 & 0.24 & 0.16 & 0.01 & 0.02 & $<0.01$ & $<0.01$ \\
\hline $\mathrm{SR}+(\%)$ & 20.9 & 21.8 & $22 \cdot 3$ & $23 \cdot 2$ & 30.5 & 21.9 & 0.82 & 0.03 & $<0.01$ & $<0.01$ \\
\hline TGC $\neq\left(\right.$ ng dry weight $\left./{ }^{\circ} \mathrm{C} \times d\right)$ & 0.20 & 0.22 & 0.27 & 0.26 & 0.34 & 0.24 & 0.01 & 0.02 & $<0.01$ & 0.01 \\
\hline
\end{tabular}

SR, survival ratio; TGC, thermal growth coefficient.

*Values are means of triplicate.

t SR $(\%)=100 \times$ final fish number/initial fish number.

$\ddagger$ TGC (ng dry weight $\left./{ }^{\circ} \mathrm{C} \times \mathrm{d}\right)=\left(W_{\mathrm{f}}^{1 / 3}-W_{\mathrm{i}}^{1 / 3}\right) \times 1000 / \Sigma(t \times$ feeding days $)$, where $W_{\mathrm{f}}$ and $W_{\mathrm{i}}$ were the final and initial fish weights, respectively, and $\Sigma(t \times$ feeding days $)$ was the sum of the water temperatures $\left({ }^{\circ} \mathrm{C}\right)$ for every feeding day in the experiment.

diet with $1.42 \%$ ARA was much higher than that in the other treatments, and the $0.01 \%$ ARA treatment showed the lowest TGC (Table 5).

\section{Activity of digestive enzymes}

The activity of trypsin in larval PS increased significantly in a 'U'-shaped manner as dietary ARA increased from 0.01 to $1.07 \%$ and decreased unsymmetrically at higher ARA concentrations. Larvae fed the diet with $2 \cdot 86 \%$ ARA showed the lowest trypsin activity in the PS. In the IS, the lowest trypsin activity was seen in the $0.01 \%$ dietary ARA treatment, and trypsin activity increased significantly in a non-linear manner to a plateau as dietary ARA increased from 0.01 to $1.42 \%$; it then decreased unsymmetrically. Lipase activity in both the PS and IS increased significantly in a ' $U$ '-shaped manner as dietary ARA increased from 0.01 to $1.42 \%$ and then decreased symmetrically, but the values of lipase activity in most of the treatments were close to each other. The highest amylase activity in the PS and IS occurred in the 0.01 and 0.39\% ARA treatments, respectively. LAP activity in both the IS and BBM increased significantly to a plateau in a non-linear manner as dietary ARA increased from 0.01 to $1.42 \%$, and then it decreased. ALP activity in the IS followed the same pattern as LAP. However, ALP activity in the BBM increased significantly in a ' $U$ '-shaped manner as dietary ARA increased from 0.01 to $1.42 \%$, and then it decreased symmetrically. The lowest ALP activity in the IS and BBM was seen in the 0.01 and $2 \cdot 86 \%$ ARA treatments, respectively (Table 6).

\section{Fatty acid composition}

The fatty acid composition of the fish larvae is presented in Table 7. SFA, $n-6$ PUFA and EPA in the larvae were much lower than in the diets, but MUFA and DHA in the larvae were higher than in the diets. Meanwhile, n-3:n-6 PUFA and DHA:EPA in the larvae were also higher than in the diets. As dietary ARA concentration increased from 0.01 to $1.42 \%$, SFA and EPA decreased significantly in a linear manner, and DHA increased in a 'U'-shaped manner and then decreased unsymmetrically. This also led to a changing ratio of DHA to EPA in fish larvae, and the larvae fed $1.42 \%$ dietary ARA had much higher DHA:EPA as compared to other treatments. Larvae fed $2 \cdot 86 \%$ dietary ARA showed the lowest SFA and DHA. On the contrary, the amount of MUFA, especially $18: 1 n-7$, in larvae fed $2 \cdot 86 \%$ dietary ARA was much higher than that in other treatments. The ARA in fish larvae increased significantly to a plateau in a non-linear manner as dietary ARA concentration increased, and the larvae fed $0.70 \%$ dietary ARA had higher $n$-6 PUFA.

Table 6. Digestive enzyme activity of larval tongue sole fed diets with graded concentrations of arachidonic acid (ARA)

(Mean values with their pooled standard errors)*

\begin{tabular}{|c|c|c|c|c|c|c|c|c|c|c|c|}
\hline \multirow[b]{2}{*}{ Digestive enzyme } & & \multicolumn{6}{|c|}{ Dietary ARA content (\% DM) } & \multirow[b]{2}{*}{ Pooled SEM } & \multicolumn{3}{|c|}{ Polynomial contrasts } \\
\hline & & 0.01 & 0.39 & 0.70 & 1.07 & 1.42 & $2 \cdot 86$ & & Linear & Quadratic & Cubic \\
\hline \multirow[t]{2}{*}{ Trypsin (mU/mg Prot) } & PS & $6 \cdot 64$ & 6.99 & 5.74 & 7.87 & 5.94 & 3.10 & 0.41 & $<0.01$ & 0.02 & NS \\
\hline & IS & 13.3 & 20.5 & 20.4 & 30.7 & 38.5 & 18.5 & 2.05 & $<0.01$ & $<0.01$ & $<0.01$ \\
\hline \multirow{2}{*}{ Lipase (U/mg Prot) } & PS & 0.42 & 0.44 & 0.55 & 0.40 & 0.58 & 0.40 & 0.02 & NS & $<0.01$ & NS \\
\hline & IS & 0.48 & 0.53 & 0.48 & 0.54 & 0.59 & 0.49 & 0.02 & NS & 0.01 & NS \\
\hline \multirow[t]{2}{*}{ Amylase (mU/mg Prot) } & PS & 4.83 & 1.74 & 3.21 & 2.58 & 2.38 & 3.85 & 0.26 & NS & $<0.01$ & $<0.01$ \\
\hline & IS & $2 \cdot 29$ & 5.43 & 4.37 & 4.04 & $2 \cdot 26$ & 4.70 & 0.30 & 0.04 & NS & $<0.01$ \\
\hline \multirow[t]{2}{*}{ LAP (mU/mg Prot) } & IS & 68.1 & $72 \cdot 4$ & 84.7 & 88.2 & 132 & 64.7 & 5.79 & NS & $<0.01$ & $<0.01$ \\
\hline & BBM & $70 \cdot 2$ & 73.5 & $49 \cdot 4$ & $82 \cdot 1$ & 108 & $48 \cdot 8$ & 4.99 & $<0.01$ & $<0.01$ & $<0.01$ \\
\hline \multirow[t]{2}{*}{ ALP (mU/mg Prot) } & IS & 253 & 314 & 334 & 361 & 634 & 314 & $27 \cdot 3$ & NS & $<0.01$ & $<0.01$ \\
\hline & BBM & 113 & 119 & 142 & 149 & 156 & 95.4 & 5.78 & NS & $<0.01$ & NS \\
\hline
\end{tabular}

Prot, protein; PS, pancreatic segment; IS, intestinal segment; LAP, leucine aminopeptidase; BBM, brush-border-membrane; ALP, alkaline phosphatise.

*Values are means of triplicate. 
Table 7. Whole-body fatty acid composition of larval tongue sole fed diets with graded concentrations of arachidonic acid (ARA, $\%$ total fatty acid)

(Mean values with their pooled standard errors) ${ }^{\star}$

\begin{tabular}{|c|c|c|c|c|c|c|c|c|c|c|}
\hline \multirow[b]{2}{*}{ Fatty acid } & \multicolumn{6}{|c|}{ Dietary ARA content ( $\%$ DM) } & \multirow[b]{2}{*}{ Pooled SEM } & \multicolumn{3}{|c|}{ Polynomial contrast } \\
\hline & 0.01 & 0.39 & 0.70 & 1.07 & 1.42 & $2 \cdot 86$ & & Linear & Quadratic & Cubic \\
\hline $14: 0$ & 0.78 & 0.84 & $1 \cdot 12$ & 0.94 & 1.04 & 0.66 & 0.44 & NS & $<0.01$ & NS \\
\hline $16: 0$ & $25 \cdot 9$ & 23.2 & 25.4 & $26 \cdot 0$ & 20.5 & $18 \cdot 6$ & 0.82 & $<0.01$ & NS & NS \\
\hline $18: 0$ & 0.77 & 0.67 & 0.62 & 0.44 & 0.78 & 0.83 & 0.05 & NS & NS & NS \\
\hline $20: 0$ & 0.55 & 0.95 & 1.28 & 1.01 & 1.30 & $1 \cdot 18$ & 0.07 & $<0.01$ & $<0.01$ & NS \\
\hline$\Sigma S F A$ & $28 \cdot 1$ & $25 \cdot 7$ & 28.4 & 28.4 & $23 \cdot 7$ & $21 \cdot 2$ & 0.80 & $<0.01$ & NS & NS \\
\hline $16: 1$ & 1.48 & $3 \cdot 76$ & $2 \cdot 81$ & $3 \cdot 21$ & 2.98 & 3.07 & 0.19 & 0.05 & $<0.01$ & $<0.01$ \\
\hline $18: 1 n-9$ & $10 \cdot 0$ & $9 \cdot 34$ & $8 \cdot 24$ & 8.91 & 8.61 & 11.7 & 0.33 & 0.01 & $<0.01$ & NS \\
\hline $18: 1 n-7$ & 21.5 & 22.0 & 18.5 & 19.5 & $19 \cdot 3$ & 26.4 & 0.75 & $<0.01$ & $<0.01$ & NS \\
\hline ¿MUFA & 33.0 & $35 \cdot 1$ & $29 \cdot 6$ & 31.6 & 30.9 & 41.2 & 1.01 & $<0.01$ & $<0.01$ & NS \\
\hline $18: 2 n-6$ & $6 \cdot 20$ & 6.52 & $7 \cdot 37$ & $6 \cdot 73$ & 5.91 & 5.29 & 0.19 & $<0.01$ & 0.04 & 0.02 \\
\hline $20: 4 n-6$ & $0 \cdot 16$ & 0.28 & 0.37 & 0.41 & 0.87 & 1.75 & 0.13 & $<0.01$ & $<0.01$ & $<0.01$ \\
\hline$\Sigma n-6$ PUFA & $6 \cdot 36$ & $6 \cdot 8$ & $7 \cdot 74$ & $7 \cdot 14$ & 6.78 & 7.04 & 0.14 & NS & NS & 0.03 \\
\hline $18: 3 n-3$ & 1.73 & $2 \cdot 15$ & 1.03 & 1.83 & $1 \cdot 12$ & $2 \cdot 81$ & 0.16 & $<0.01$ & $<0.01$ & NS \\
\hline $20: 5 n-3$ & $3 \cdot 16$ & 3.07 & 3.02 & 2.75 & 2.46 & 2.40 & 0.10 & 0.01 & NS & NS \\
\hline $22: 6 n-3$ & $10 \cdot 3$ & 10.5 & $12 \cdot 9$ & 11.0 & $12 \cdot 6$ & 8.89 & 0.37 & 0.02 & $<0.01$ & NS \\
\hline$\Sigma n-3$ PUFA & $15 \cdot 2$ & $15 \cdot 7$ & $16 \cdot 9$ & $15 \cdot 6$ & $16 \cdot 2$ & $14 \cdot 1$ & 0.30 & NS & 0.04 & NS \\
\hline$\sum n-3: \sum n-6$ PUFA & $2 \cdot 39$ & $2 \cdot 32$ & $2 \cdot 19$ & $2 \cdot 21$ & $2 \cdot 39$ & 2.00 & 0.06 & NS & NS & NS \\
\hline DHA:EPA & 3.29 & 3.44 & $4 \cdot 34$ & 4.02 & $5 \cdot 14$ & $3 \cdot 71$ & 0.17 & NS & $<0.01$ & NS \\
\hline EPA:ARA & $20 \cdot 3$ & $10 \cdot 8$ & $8 \cdot 19$ & $6 \cdot 73$ & $2 \cdot 82$ & 1.37 & 1.51 & $<0.01$ & $<0.01$ & $<0.01$ \\
\hline
\end{tabular}

* Some fatty acids, of which the contents were minor, in trace amounts or not detected (such as 22:0, 24:0, 14:1, 20:1n-9, 22:1n-11, 20:2n-6, $20: 3 n-6$ and $22: 5 n-3)$, are not listed in Table 7. Data are means of triplicate.

\section{Partial nucleotide sequences of arachidonic acid metabolism-related genes}

The present study obtained the partial nucleotide sequences of COX-1a,COX-1b,COX-2, 5-LOX and CYP2J6-like cDNA and the nucleotide sequence data of these genes have been deposited in the GenBank nucleotide sequence database under accession no. KF533723, KF533724, KF533725, KF533726 and KJ578726, respectively. The sequence of COX-1a revealed a fragment of 788 bp that was highly homologous to Myoxocephalus octodecemspinosus (81\%) and Fundulus beteroclitus ( $81 \%$ ), and the sequence of COX-1b revealed a fragment of $772 \mathrm{bp}$ that was also highly homologous to $M$. octodecemspinosus ( $81 \%$ ) and $F$. heteroclitus ( $81 \%)$. The sequence of $C O X-2$ revealed a fragment of 1037 bp that was highly homologous to Oplegnathus fasciatus (82\%), Micropogonias undulates (81\%) and Pagrus major (80\%). The sequence of $5-L O X$ revealed a fragment of 1014 bp that was highly homologous to Oreochromis niloticus (81\%), Maylandia zebra (80\%) and Takifugu rubripes (79\%). The sequence of CYP2J6-like revealed a fragment of $871 \mathrm{bp}$ that was highly homologous to Pundamilia nyererei $(76 \%)$, Haplochromis burtoni (76\%) and M. zebra (76\%)

\section{Arachidonic acid metabolism-related gene expression}

The relative mRNA expression levels of ARA metabolism-related genes (COX-1a, COX-1b, COX-2, 5-LOX and CYP2J6-like) in the visceral mass of larvae that were fed diets with graded concentrations of ARA is presented in Figs. 1 and 2. The relative expression of $C O X-1 a$ and $C O X-1 b$ showed similar changing trends with increased dietary ARA, but few differences were found in the relative expression of both $C O X-1 a$ and $C O X-1 b$ among the dietary treatments. Both the COX-2 and 5-LOX mRNA expression levels significantly increased to a plateau in an ' $\mathrm{L}$ '-shaped manner, and the maximum expression levels of $C O X-2$ and 5-LOX were seen in the 1.42 and $1.07 \%$ dietary ARA treatments, respectively. The expression level of $C O X-2$ increased approximately 0.68 - and 0.25 -fold in the treatments with 1.42 and $2 \cdot 86 \%$ dietary ARA, respectively (Fig. 2(a)), and the expression levels of 5-LOX were increased about 0.61- and 0.60 -fold in the treatments with 1.07 and $1.42 \%$ dietary ARA, respectively (Fig. 2(b)). Although the expression levels of CYP2J6-like transcript were up-regulated to a maximum as dietary ARA increased from 0.01 to $1.42 \%$ and were then down-regulated, little difference was observed (Fig. 2(c)).

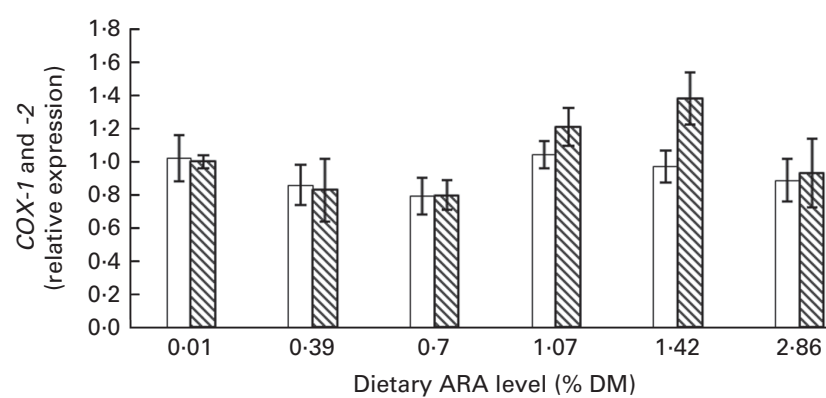

Fig. 1. Relative mRNA expression of cyclo-oxygenase (COX)-1a and COX$1 b$ in the visceral mass of larval tongue sole (Cynoglossus semilaevis) fed with graded concentrations of arachidonic acid (ARA). Relative mRNA expression was evaluated by real-time quantitative PCR. Values are means ( $n$ 3), with their standard errors represented by vertical bars. COX-1a ( $\square$ ): $P_{\text {linear }}=0.82 ; \quad P_{\text {quadratic }}=0.92 ; \quad P_{\text {cubic }}=0.18 . \quad \operatorname{COX}-1 b(\mathbb{\nabla}): P_{\text {linear }}=0.55$; $P_{\text {quadratic }}=0.08 ; P_{\text {cubic }}=0.06$ 

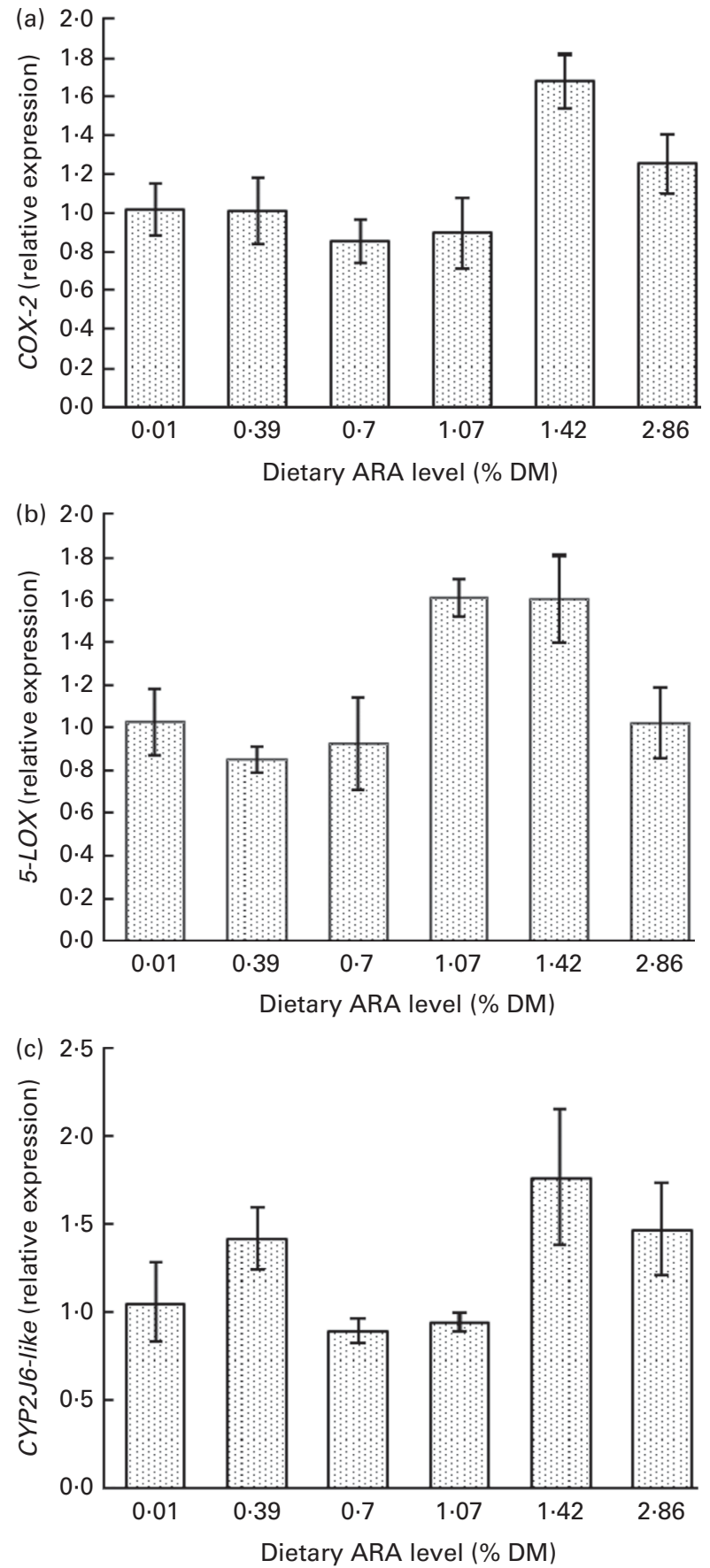

Fig. 2. Relative mRNA expression of cyclo-oxygenase (COX)-2 (a), 5-lipoxygenase (5-LOX) (b) and cytochrome P450 2J6-like (CYP2J6-like) (c) in the visceral mass of larval tongue sole (Cynoglossus semilaevis) fed with graded concentrations of arachidonic acid (ARA). Relative mRNA expression was evaluated by real-time quantitative PCR. Values are means $(n 3)$, with their standard errors represented by vertical bars. $\operatorname{COX}-2$ (图): $P_{\text {linear }}=0.04$ $P_{\text {quadratic }}=0.33 ; P_{\text {cubic }}<0.01 .5$-LOX $($ 圆 $): P_{\text {linear }}=0.35 ; P_{\text {quadratic }}<0.01 ;$ $P_{\text {cubic }}=0.02$. CYP2J6-like (圆): $P_{\text {linear }}=0.14 ; P_{\text {quadratic }}=0.80 ; P_{\text {cubic }}=0.20$.

\section{Discussion}

The results of the present study demonstrated that the growth and survival of larval tongue sole responded to dietary ARA with a non-linear raise to a plateau, which implies that appropriate ARA is important for larval tongue sole to maintain normal rapid growth and physiological function, but deficient or excessive dietary ARA restrains their development. These results agreed well with many previous studies in several fish species $^{(3,7,10,13)}$. In particular, in the present study, the larvae fed $1.42 \%$ dietary ARA had significantly higher growth and survival rates as compared to the other groups, which indicates that the optimal requirement for dietary ARA for larval tongue sole is approximately $1.42 \%$ (dry weight). This is comparable to studies on larval gilthead sea bream $^{(7)}$, larval European sea bass ${ }^{(25)}$ and larval Senegal sole ${ }^{(12)}$, but some other studies have reported lower requirements for dietary ARA for several fish species during larval development, such as black sea bass ${ }^{(16)}$, summer flounder ${ }^{(13)}$ and gilthead sea bream ${ }^{(69)}$. These differences were probably a result of the fish species, study methods and culture systems. In addition, it was noticed that all of the treatments in the present study obtained relatively high mortalities and low growth rates, which might be related to the characteristic lethargic browsing feeding habit of larval tongue sole ${ }^{(50)}$; the results of the survival and growth rates were comparable to those in several previous studies ${ }^{(51,58)}$.

The relative levels of ARA and EPA have also been suggested to be important for the normal growth of larval fish; the optimal dietary EPA:ARA ratio is likely speciesspecific, but it should probably be about $5: 1^{(70,71)}$. In the present study, it is noteworthy that the dietary EPA:ARA ratio in the best growth and survival group was quite low (0.59, shown in Table 2), which is similar to other studies on ARA nutrition in larval gilthead sea bream ${ }^{(7)}$ and summer flounder ${ }^{(13)}$. However, in the present study, the EPA:ARA ratio of larval tongue sole with the best growth and survival was much higher $(2 \cdot 82$, shown in Table 7$)$ than in the diets. This indicates that the dietary EPA:ARA ratio might be of less importance than dietary ARA concentration for larval tongue sole, seeing as larval tongue sole were seemingly able to regulate the ratio of EPA:ARA in their bodies, even though a low dietary EPA:ARA ratio was provided.

Previous studies demonstrated that PUFA was conserved preferentially at the expense of SFA and MUFA ${ }^{(14,72)}$. Specific fatty acids are either selectively retained or metabolised, and preferential metabolism often occurs when a particular fatty acid is supplied at high concentrations in the diet ${ }^{(73)}$. In the present study, SFA, $n-6$ PUFA and EPA in the larvae were declined as compared to those in the diets, but MUFA showed a contrary trend. This implied that the SFA, n-6 PUFA and EPA provided in the diets were possibly abundant for larval tongue sole and metabolised preferentially, and part of the SFA might be desaturated and elongated to form MUFA. In addition, higher n-3:n-6 PUFA and DHA:EPA ratios in the larvae were observed as compared to the diets, which reflects the conservation priority of $n-3$ to $n-6$ PUFA and DHA to EPA. This conformed with previous studies ${ }^{(74-76)}$. Moreover, in the present study, increased dietary ARA concentration resulted in a concomitant increase of ARA in larvae, which is similar to reports in other fish species $^{(6,12)}$. Meanwhile, the higher ARA concentration in the diets than in the fish also indicates that except when it was integrated 
into the membranes, part of the exogenous ARA was probably metabolised preferentially through $\beta$-oxidation for energy production when it was supplied at high concentrations in the diet ${ }^{(73)}$. Despite almost constant EPA in the diets, the EPA contents of the larvae in the present study generally declined in a linear manner as dietary ARA increased. This agreed well with investigations on summer flounder ${ }^{(13)}$, gilthead seabream $^{(23)}$, Senegal sole ${ }^{(12)}$ and Japanese seabass ${ }^{(3)}$. Atalah et $a l^{(17)}$ proposed that dietary ARA was more efficiently incorporated into larval tissues than EPA, which could be related to a higher affinity of TAG and phospholipid biosynthesis enzymes stimulated by $n$ - 6 fatty acids ${ }^{(77)}$, and the increased incorporation of ARA into the larval lipids slightly reduced EPA incorporation when the latter was high in the diet.

To some extent, digestive enzyme activity could reflect the development of the larval digestive tract, and the ability of larvae to assimilate the required nutrients generally depends on the capacity of their digestive tracts to modulate digestive enzymes and metabolic processes ${ }^{(78)}$. Digestive enzyme activity in fish varies among species, but it can be influenced by age as well as by the quantity and composition of the diet ${ }^{(79)}$. Surprisingly, however, no information is available on the effects of dietary ARA concentrations on digestive enzyme activity in larval fish. The exocrine pancreas synthesises and secretes several enzymes, including proteases, lipases and amylases, in the intestinal lumen ${ }^{(80)}$. In vertebrates, the protease precursor trypsinogen is synthesised and stored in the pancreas, and it is rapidly converted into active trypsin when it is released into the intestine ${ }^{(81)}$. The acquisition of an efficient secretory function in the pancreas characterises the maturation of pancreas ${ }^{(82)}$. In the intestine, an increase in the folding of the mucosa is concomitant with a strong elevation in the activity of some digestive enzymes located in the cell membranes ${ }^{(59)}$. ALP and LAP, both of which are intestinal enzymes, are located in the BBM of enterocytes ${ }^{(78)}$. ALP is believed to be involved in the absorption of nutrients such as lipids, glucose, $\mathrm{Ca}$ and inorganic phosphate ${ }^{(83)}$, and a strong increase in ALP activity reflects the development of the BBM of enterocytes, which occurs concurrently with a decrease in cytosolic enzymes ${ }^{(59)}$. LAP is often viewed as a cell maintenance enzyme that plays critical role in the turnover of peptides and the final step in protein degradation, which shows high activity throughout the larval phase $^{(84)}$. An increase in aminopeptidase $\mathrm{N}$ in the intestinal BBM characterises the normal maturation of the enterocytes in fish larvae ${ }^{(80)}$.

Previous studies have reported that trypsin secretion was positively regulated by the dietary protein level as well as the chain length and maturity of the pancreas ${ }^{(80,85)}$. Dietary protein level and chain length were therefore kept the same in the present study. The larvae fed 1.07-1.42\% dietary ARA showed higher trypsin activity in both the PS and IS than those in the other treatments, which indicates that moderate dietary ARA contributes to a better maturation and functionality of the pancreas, and insufficient or excessive ARA might delay pancreas maturation. In fish species, lipase is secreted by the hepatopancreas mainly in response to the presence of TAG in the lumen ${ }^{(86)}$. Cahu et al. ${ }^{(87)}$ even found that the response of lipase was positively correlated with dietary TAG levels in sea bass larvae. In the present study, indistinctive changing trends of lipase activity in both the PS and IS were observed, which were possibly related to the almost constant lipid content and mainly methylester-form lipid in all of the diets. Because a decline in amylase activity was observed during the normal maturation process of the fish larvae, the lower amylase activity in the $1.42 \%$ dietary ARA treatment could also be considered an indicator of the maturation of the exocrine pancreas in the present study ${ }^{(79,88)}$. Moreover, in the present study, elevated levels of ALP and LAP activity in the $1.42 \%$ dietary ARA treatment were observed, which implies that moderate dietary ARA also promotes the maturation of enterocytes in the BBM in developing larval tongue sole. Overall, dietary ARA seemed to play a role in regulating the development of the digestive tract and consequently influenced the growth and survival rates of larval tongue sole. However, the mechanism by which dietary ARA affected digestive tract development is unclear, and further studies are needed to investigate this mechanism.

In mammals, ARA is metabolised into eicosanoids mainly through three different pathways, namely, COX, LOX and CYP enzymes ${ }^{(31)}$. In the present study, the partial sequences of COX-1a,COX-1b,COX-2, 5-LOX and CYP2J6-like were obtained. COX catalyses the first committed step in the biosynthesis of $\mathrm{PG}$ through the conversion of ARA to $\mathrm{PGH}_{2}^{(89)}$. COX-1 and COX-2 are two isozymes of $\mathrm{COX}^{(90)}$. In the present study, two $C O X-1$ genes (COX-1a and $C O X-1 b)$ and one $C O X-2$ gene were cloned in tongue sole, and this result was similar to reports on Tetraodon nigroviridis, T. rubripes and Oryzias latipes $^{(91)}$. The additional copies of $C O X-1$ and $C O X-2$ were likely the result of a teleost-specific genome duplication event $^{(92)}$. 5-LOX is a member of the family of $\mathrm{LOX}^{(41)}$ and is the rate-limiting enzyme in LT synthesis ${ }^{(42)}$. A partial sequence of putative 5-LOX CDNA was obtained in the present study. As mentioned earlier, it was highly homologous to 5-LOX cDNA of O. niloticus (81\%), M. zebra (80\%) and T. rubripes (79\%). CYP enzymes catalyse the epoxidation of ARA to form $\mathrm{EET}^{(44,45)}$. In vertebrates, CYP2J subfamilies are recognised as catalysts of ARA metabolism in the extrahepatic tissues of many species, such as CYP2J9 in mice ${ }^{(93)}$ and CYP2J1 in zebrafish ${ }^{(46)}$. However, in the present study, only a partial sequence of a cDNA (CYP2J6-like) encoding a putative CYP2J6 protein was obtained, and the function of CYP2J6-like should be identified in future experiments.

In an effort to elucidate the mechanisms by which dietary ARA modulates growth performance of larval tongue sole, the effects of dietary ARA concentrations on ARA metabolism-related gene (COX-1a, COX-1b, COX-2, 5-LOX and CYP2J6-like) expression were investigated. In the present study, no significant differences were observed in the mRNA expression of both $C O X-1 a$ and $C O X-1 b$, which indicates that both $C O X-1$ genes were not regulated by dietary ARA, at least on the transcriptional level. This conformed to the characterisation of $C O X-1$ as a 'housekeeping' gene that is constitutively expressed in almost all tissues ${ }^{(94)}$. However, it has been reported that dietary $n-6$ PUFA (safflower oil) could up-regulate $C O X-1$ expression to some extent in rat mammary glands, but dietary $n-3$ PUFA 
(menhaden oil) could not do so ${ }^{(95)}$. Different animal species, sampling tissue and diet formulation might account for these inconsistent results. Similar to COX-1, the expression of CYP2J6-like also did not show much difference among the dietary treatments in the present study. In in vitro studies, CYP2J has been reported to be constitutively expressed in cultured human endothelial cells ${ }^{(96,97)}$, and CYP2J6-like mRNA in the present study might have been expressed in the same pattern. In medical research, $C O X-2$ has been shown to be rapidly and dramatically up-regulated in inflammatory responses $^{(94)}$, and overexpressed 5-LOX has resulted in the excessive generation of pro-inflammatory LT, which may contribute to atherosclerosis and cancer ${ }^{(42)}$. However, $\mathrm{COX}-2$ and 5-LOX have also been shown to express to certain levels and contribute to maintaining fundamental physiological function under normal or basal conditions ${ }^{(28,94)}$. Obviously, the expression values of $C O X-2$ and 5-LOX mRNA in all of the treatments in the present study were nowhere near overexpression. Meanwhile, in the present study, both the $C O X-2$ and 5-LOX mRNA expression levels varied asymmetrically in response to dietary ARA, and the maximum expression levels of COX-2 and 5-LOX occurred in the 1.42 and $1.07 \%$ dietary ARA treatments, respectively. Higher expression of $C O X-2$ and 5-LOX and better growth rates, survival rates and digestive tract development were found in the same treatments. Both COX-2- and 5-LOX-dependent ARA metabolites have been reported as essential to the development and maintenance of intestinal immune homeostasis ${ }^{(98,99)}$. This implies that both $C O X-2$ and $5-L O X$ probably played a role in improving digestive tract development and consequently the growth performance of larval tongue sole by altering their mRNA expression.

To conclude, dietary ARA concentration significantly influenced survival rates, growth rates, digestive enzyme activity, fatty acid composition and some ARA metabolismrelated gene expression in larval tongue sole, and a relatively higher dietary ARA concentration (1.07-1.42\%) enhanced the growth performance of larval tongue sole. The regulation of dietary ARA on growth performance in fish larvae was probably involved in altering the mRNA expression levels of $C O X-2$ and 5-LOX. Further study is required to determine the effects of dietary ARA concentrations on ARA metabolites and the mechanism that underlies the participation of ARA metabolites in physiological activities.

\section{Acknowledgements}

We thank Y. X. Li, K. Lu, Y. L. Liu, P. Yang and J. Yan for their help in manufacturing the diets as well as S. Zhang, B. Han, X. J. Dong and J. T. Guan for their help during the sampling.

The present study was supported by the National Basic Research Program of China (973 Program) (2014CB138600), the China Agriculture Research System (CARS-50-G08) and Agricultural Scientific and Technological Achievements into Capital (2010GB23600673). The China Agriculture Research System and Agricultural Scientific and Technological Achievements into Capital had no role in the design, analysis or writing of the present article.
Y. Y. designed all of the experiments, carried out the experimental work and wrote the manuscript under the direction of the project leader Q. A. and K. M.; S. L. assisted with the experimental work and manuscript writing; Q. A. also assisted with the experimental design and manuscript revision; W. X. and Y. Z. provided all of the fatty acid composition data.

There are no conflicts of interest to report.

\section{References}

1. Koven W, Barr Y, Lutzky S, et al. (2001) The effect of dietary arachidonic acid $(20: 4 n-6)$ on growth, survival and resistance to handling stress in gilthead seabream (Sparus aurata) larvae. Aquaculture 193, 107-122.

2. Bell JG \& Sargent JR (2003) Arachidonic acid in aquaculture feeds: current status and future opportunities. Aquaculture 218, 491-499.

3. Xu HG, Ai QH, Mai KS, et al. (2010) Effects of dietary arachidonic acid on growth performance, survival, immune response and tissue fatty acid composition of juvenile Japanese seabass, Lateolabrax japonicus. Aquaculture 307, 75-82.

4. Needleman P, Jakschik BA, Morrison AR, et al. (1986) Arachidonic acid metabolism. Annu Rev Biochem 55, 69-102.

5. Zeldin DC (2001) Epoxygenase pathways of arachidonic acid metabolism. J Biol Chem 276, 36059-36062.

6. Bransden MP, Cobcroft JM, Battaglene SC, et al. (2004) Dietary arachidonic acid alters tissue fatty acid profile, whole body eicosanoid production and resistance to hypersaline challenge in larvae of the temperate marine fish, striped trumpeter (Latris lineata). Fish Physiol Biochem 30, 241-256.

7. Bessonart M, Izquierdo MS, Salhi M, et al. (1999) Effect of dietary arachidonic acid levels on growth and survival of gilthead sea bream (Sparus aurata L.) larvae. Aquaculture 179, $265-275$.

8. Carrier JK, Watanabe WO, Harel M, et al. (2011) Effects of dietary arachidonic acid on larval performance, fatty acid profiles, stress resistance, and expression of $\mathrm{Na}^{+} / \mathrm{K}^{+}$ ATPase mRNA in black sea bass (Centropristis striata). Aquaculture 319, 111-121.

9. Lund I, Steenfeldt SJ \& Hansen BW (2007) Effect of dietary arachidonic acid, eicosapentaenoic acid and docosahexaenoic acid on survival, growth and pigmentation in larvae of common sole (Solea solea L.). Aquaculture 273, 532-544.

10. Luo Z, Tan XY, Li XD, et al. (2012) Effect of dietary arachidonic acid levels on growth performance, hepatic fatty acid profile, intermediary metabolism and antioxidant responses for juvenile Synechogobius hasta. Aquacult Nutr 18, 340-348.

11. Martins DA, Rocha F, Castanheira F, et al. (2013) Effects of dietary arachidonic acid on cortisol production and gene expression in stress response in Senegalese sole (Solea senegalensis) post-larvae. Fish Physiol Biochem 39, 1223-1238.

12. Villalta M, Estévez A \& Bransden MP (2005) Arachidonic acid enriched live prey induces albinism in Senegal sole (Solea senegalensis) larvae. Aquaculture 245, 193-209.

13. Willey S, Bengtson DA \& Harel M (2003) Arachidonic acid requirements in larval summer flounder, Paralichthys dentatus. Aquacult Int 11, 131-149.

14. Rainuzzo JR, Reitan KI, Jorgensen L, et al. (1994) Lipid composition in turbot larvae fed live feed cultured by emulsions of different lipid classes. Comp Biochem Physiol 107, $699-710$

15. Izquierdo MS (1996) Essential fatty acid requirements of cultured marine fish larvae. Aquacult Nutr 2, 183-191. 
16. Rezek TC, Watanabe WO, Harel M, et al. (2010) Effects of dietary docosahexaenoic acid $(22: 6 n-3)$ and arachidonic acid $(20: 4 n-6)$ on the growth, survival, stress resistance and fatty acid composition in black sea bass Centropristis striata (Linnaeus 1758) larvae. Aquacult Res 41, 1302-1314.

17. Atalah E, Hernández-Cruz CM, Benítez-Santana T, et al. (2011) Importance of the relative levels of dietary arachidonic acid and eicosapentaenoic acid for culture performance of gilthead seabream (Sparus aurata) larvae. Aquacult Res 42, 1279-1288.

18. Kobayashi M, Sorensen PW \& Stacey NE (2002) Hormonal and pheromonal control of spawning behavior in the goldfish. Fish Physiol Biochem 26, 71-84.

19. Emata AC, Ogata HY, Garibay ES, et al. (2003) Advanced broodstock diets for the mangrove red snapper and a potential importance of arachidonic acid in eggs and fry. Fish Physiol Biochem 28, 489-491.

20. Furuita H, Yamamoto T, Shima T, et al. (2003) Effect of arachidonic acid levels in broodstock diet on larval and egg quality of Japanese flounder Paralichthys olivaceus. Aquaculture 220, 725-735.

21. Meunpol O, Meejing P \& Piyatiratitivorakul S (2005) Maturation diet based on fatty acid content for male Penaeusmonodon (Fabricius) broodstock. Aquacult Res 36, 1216-1225.

22. Ohs CL, DiMaggio MA, Grabe SW, et al. (2013) Effects of increasing docosahexaenoic acid (DHA) and arachidonic acid (ARA) in brood diets of monodactylussebae on fecundity, egg and larval quality, and egg fatty acid composition. N Am J Aquacult 75, 285-294.

23. Van Anholt RD, Koven WM, Lutzky S, et al. (2004) Dietary supplementation with arachidonic acid alters the stress response of gilthead seabream (Sparus aurata) larvae. Aquaculture 238, 369-383.

24. Van Anholt RD, Spanings FAT, Nixon O, et al. (2012) The effects of arachidonic acid on the endocrine and osmoregulatory response of tilapia (Oreochromis mossambicus) acclimated to seawater and subjected to confinement stress. Fish Physiol Biochem 38, 703-713.

25. Atalah E, Hernández-Cruz CM, Ganuza E, et al. (2011b) Importance of dietary arachidonic acid for the growth, survival and stress resistance of larval European sea bass (Dicentrarchus labrax) fed high dietary docosahexaenoic and eicosapentaenoic acids. Aquacult Res 42, 1261-1268.

26. Copeman LA, Parrish CC, Brown JA, et al. (2002) Effects of docosahexaenoic, eicosapentaenoic, and arachidonic acids on the early growth, survival, lipid composition and pigmentation of yellowtail flounder (Limanda ferruginea): a live food enrichment experiment. Aquaculture 210, 285-304.

27. Lund I, Steenfeldt SJ, Banta G, et al. (2008) The influence of dietary concentrations of arachidonic acid and eicosapentaenoic acid at various stages of larval ontogeny on eye migration, pigmentation and prostaglandin content of common sole larvae (Solea solea L.). Aquaculture 276, 143-153.

28. Estevez A, Ishikawa M \& Kanazawa A (1997) Effects of arachidonic acid on pigmentation and fatty acid composition of Japanese flounder, Paralichthys olivaceus (Temminck and Schlegel). Aquacult Res 28, 279-289.

29. Bransden MP, Butterfield GM, Walden J, et al. (2005) Tank colour and dietary arachidonic acid affects pigmentation, eicosanoid production and tissue fatty acid profile of larval Atlantic cod (Gadus morbua). Aquaculture 250, 328-340.

30. Li QF, Ai QH, Mai KS, et al. (2012) In vitro effects of arachidonic acid on immune functions of head kidney macrophages isolated from large yellow croaker (Larmichthys crocea). Aquaculture 330, 47-53.
31. Astudillo AM, Balgoma D, Balboa MA, et al. (2012) Dynamics of arachidonic acid mobilization by inflammatory cells. Biochim Biophys Acta 1821, 249-256.

32. Rifkind AB, Lee C, Chang TK, et al. (1995) Arachidonic acid metabolism by human cytochrome P450s 2C8, 2C9, 2E1, and 1A2: regioselective oxygenation and evidence for a role for CYP2C enzymes in arachidonic acid epoxygenation in human liver microsomes. Arch Biochem Biophys 320, 380-389.

33. Samuelsson B (1990) Arachidonic acid metabolism: role in inflammation. $Z$ Rheumatol 50, 3-6.

34. Campbell WB, Gebremedhin D, Pratt PF, et al. (1996) Identification of epoxyeicosatrienoic acids as endothelium-derived hyperpolarizing factors. Circ Res 78, 415-423.

35. Brash AR (1999) Lipoxygenases: occurrence, functions, catalysis, and acquisition of substrate. J Biol Chem $\mathbf{2 7 4}$, 23679-23682.

36. Oxley A, Jolly C, Eide T, et al. (2010) The combined impact of plant-derived dietary ingredients and acute stress on the intestinal arachidonic acid cascade in Atlantic salmon (Salmo salar). Br J Nutr 103, 851-861.

37. Langenbach R, Morham SG, Tiano HF, et al. (1995) Prostaglandin synthase 1 gene disruption in mice reduces arachidonic acid-induced inflammation and indomethacininduced gastric ulceration. Cell 83, 483-492.

38. Dubois RN, Abramson SB, Crofford L, et al. (1998) Cyclooxygenase in biology and disease. FASEB J 12, 1063-1073.

39. Legler DF, Bruckner M, Uetz-von Allmen E, et al. (2010) Prostaglandin $\mathrm{E}_{2}$ at new glance: novel insights in functional diversity offer therapeutic chances. Int J Biochem Cell Biol 42, 198-201.

40. Vane JR, Bakhle YS \& Botting RM (1998) Cyclooxygenase 1 and 2. Annu Rev Pharmacol Toxicol 38, 97-120.

41. Ford-Hutchinson AW, Gresser M \& Young RN (1994) 5-Lipoxygenase. Annu Rev Biochem 63, 383-417.

42. Mehrabian M, Allayee H, Wong J, et al. (2002) Identification of 5-lipoxygenase as a major gene contributing to atherosclerosis susceptibility in mice. Circ Res 91, 120-126.

43. Kirischian N, McArthur AG, Jesuthasan C, et al. (2011) Phylogenetic and functional analysis of the vertebrate cytochrome P450 2 family. J Mol Evol 72, 56-71.

44. Zeldin DC, Foley J, Ma J, et al. (1996) CYP2J subfamily P450s in the lung: expression, localization, and potential functional significance. Mol Pharmacol 50, 1111-1117.

45. Capdevila JH, Falck JR \& Harris RC (2000) Cytochrome P450 and arachidonic acid bioactivation: molecular and functional properties of the arachidonate monooxygenase. J Lipid Res 41, 163-181.

46. Wang L, Yao J, Chen L, et al. (2007) Expression and possible functional roles of cytochromes P450 2J1 (zfCyp 2J1) in zebrafish. Biochem Biophys Res Commun 352, 850-855.

47. Capdevila JH, Falck JR \& Imig JD (2007) Roles of the cytochrome $\mathrm{P} 450$ arachidonic acid monooxygenases in the control of systemic blood pressure and experimental hypertension. Kidney Int 72, 683-689.

48. Zordoky BN \& El-Kadi AO (2010) Effect of cytochrome P450 polymorphism on arachidonic acid metabolism and their impact on cardiovascular diseases. Pharmacol Ther $\mathbf{1 2 5}$, $446-463$.

49. Liu XZ, Xu YJ, Ma AJ, et al. (2004) Effects of salinity, temperature, light rhythm and light intensity on embryonic development of Cynoglossus semilaevis Günther and its hatching technology optimization. Mar Fish Res 25, 1-6.

50. Ma AJ, Liu XZ, Xu YJ, et al. (2006) Feeding rhythm and growth of the tongue sole, Cynoglossus semilaevis Günther, during its early life stages. Aquacult Res 37, 586-593. 
51. Chang Q, Liang MQ, Wang JL, et al. (2006) Influence of larval co-feeding with live and inert diets on weaning the tongue sole Cynoglossus semilaevis. Aquacult Nutr 12, 135-139.

52. Liu F, Ai QH, Mai KS, et al. (2008) Effects of dietary binders on survival and growth performance of postlarval tongue sole, Cynoglossus semilaevis (Günther). J World Aquacult Soc 39, 500-509.

53. Tian X, Fang J \& Dong S (2010) Effects of starvation and recovery on the growth, metabolism and energy budget of juvenile tongue sole (Cynoglossus semilaevis). Aquaculture 310, 122-129.

54. Boglino A, Darias MJ, Andree KB, et al. (2014) The effects of dietary arachidonic acid on bone in flatfish larvae: the last but not the least of the essential fatty acids. J Appl Ichthyol 30, 643-651.

55. Houde ED (1997) Patterns and trends in larval-stage growth and mortality of teleost fish. J Fish Biol 51, 52-83.

56. Association of Official Analytical Chemist (AOAC) (1995) Official Methods of Analysis of AOAC International, 16th ed. Arlington, VA: AOAC, Inc.

57. Metcalfe LD, Schmitz AA \& Pelka JR (1996) Rapid preparation of fatty acid esters from lipids for gas chromatographic analysis. $J$ Anal Chem 38, 514-515.

58. Ai QH, Zhao JZ, Mai KS, et al. (2008) Optimal dietary lipid level for large yellow croaker (Pseudosciaena crocea) larvae. Aquacult Nutr 14, 515-522.

59. Ribeiro L, Zambonino-Infante JL, Cahu C, et al. (1999) Development of digestive enzymes in larvae of Solea senegalensis, Kaup 1858. Aquaculture 179, 465-473.

60. Crane RK, Boge G \& Rigal A (1979) Isolation of brush border membranes in vesicular form from the intestinal spiral valve of the small dogfish (Scyliorbinus canicula). Biochim Biophys Acta 554, 264-267.

61. Zambonino Infante JL, Cahu CL \& Péres A (1997) Partial substitution of di- and tripeptides for native protein in sea bass diet improves Dicentrarchus labrax larval development. J Nutr 127, 604-614.

62. Holm H, Hanssen LE, Krogdahl A, et al. (1988) High and low inhibitor soybean meals affect human duodenal proteinase activity differently: in vivo comparison with bovine serum albumin. J Nutr 118, 515-520.

63. Métais P \& Bieth J (1968) Détermination de I' $\alpha$-amylase par une microtechnique (Determination of alpha-amylase by a micromethod). Ann Biol Clin 26, 133-142.

64. Brockman HL (1981) Triglyceride lipase from porcine pancreas: EC 3.1.1.3 triacylglycerol acylhydrolase. Methods Enzymol 71, 619-627.

65. Bessey OA, Lowry OH \& Brock M (1946) Rapid coloric method for determination of alkaline phosphatase in five cubic millimeters of serum. J Biol Chem 164, 321-329.

66. Appel W (1974) Leucine aminopeptidase determination with L-leucineamide as substrate. In Methods of Enzymatic Analysis, pp. 954-958. New York: Academic Press.

67. Bradford MM (1976) A rapid and sensitive method for the quantitation of microgram quantities of protein utilizing the principle of protein-dye binding. Anal Biochem $\mathbf{7 2}$, 248-254.

68. Livak KJ \& Schmittgen TD (2001) Analysis of relative gene expression data using real-time quantitative PCR and the $2^{-\Delta \Delta C_{t}}$ method. Methods 25, 402-408.

69. Fountoulaki E, Alexis MN, Nengas I, et al. (2003) Effects of dietary arachidonic acid (20:4n-6), on growth, body composition, and tissue fatty acid profile of gilthead bream fingerlings (Sparus aurata L.). Aquaculture 225, 309-323.
70. Sargent J, McEvoy L, Estevez A, et al. (1999) Lipid nutrition of marine fish during early development: current status and future directions. Aquaculture 179, 217-229.

71. Bell JG, McEvoy LA, Estevez A, et al. (2003) Optimising lipid nutrition in first-feeding flatfish larvae. Aquaculture 227, 211-220.

72. Falk-Petersen S, Sargent JR, Fox C, et al. (1989) Lipids in atlantic halibut (Hippoglossus hippoglossus) eggs from planktonic samples in Northern Norway. Mar Biol 101, 553-556.

73. Karalazos V, Bendiksen EA, Dick JR, et al. (2007) Effects of dietary protein, and fat level and rapeseed oil on growth and tissue fatty acid composition and metabolism in Atlantic salmon (Salmo salar L.) reared at low water temperatures. Aquacult Nutr 13, 256-265.

74. Watanabe $\mathrm{T}$ (1993) Importance of docosahexaenoic acid in marine larval fish. $J$ World Aquacult Soc 24, 152-161.

75. Luo Z, Liu X, Bai H, et al. (2008) Effects of dietary fatty acid composition on muscle composition and hepatic fatty acid profile in juvenile Synechogobius hasta. J Appl Ichthyol 24, 116-119.

76. Sharma P, Kumar V, Sinha AK, et al. (2010) Comparative fatty acid profiles of wild and farmed tropical freshwater fish rohu (Labeo rohita). Fish Physiol Biochem 36, 411-417.

77. Caballero MJ, Gallardo G, Robaina L, et al. (2006) Vegetable lipid sources affect in vitro biosynthesis of triacylglycerols and phospholipids in the intestine of sea bream (Sparus aurata). Br J Nutr 95, 448-454.

78. Cahu CL \& Zambonino Infante JL (2001) Substitution of live food by formulated diets in marine fish larvae. Aquaculture 200, 161-180.

79. Péres A, ZamboninoInfante JL \& Cahu CL (1998) Dietary regulation of activities and mRNA levels of trypsin and amylase in sea bass (Dicentrarchus labrax) larvae. Fish Physiol Biochem 19, 145-152.

80. Zambonino Infante JL \& Cahu CL (2001) Ontogeny of the gastrointestinal tract of marine fish larvae. Comp Biochem Physiol C 130, 477-487.

81. Fange R \& Grove D (1979) Digestion. In Fish Physiology, vol. 8, pp. 178-189 [WS Hoar, DJ Randall and JR Brett, editors]. New York: Academic Press.

82. Tovar D, Zambonino J, Cahu C, et al. (2002) Effect of live yeast incorporation in compound diet on digestive enzyme activity in sea bass (Dicentrarchus labrax) larvae. Aquaculture 204, 113-123.

83. Tengjaroenkul B, Smith BJ, Caceci T, et al. (2000) Distribution of intestinal enzyme activities along the intestinal tract of cultured Nile tilapia, Oreochromis niloticus L. Aquaculture 182, 317-327.

84. Matsui M, Fowler JH \& Walling LL (2006) Leucine aminopeptidases: diversity in structure and function. Biol Chem 387, 1535-1544.

85. Cahu CL, Rønnestad I, Grangier V, et al. (2004) Expression and activities of pancreatic enzymes in developing sea bass larvae (Dicentrarchus labrax) in relation to intact and hydrolysed dietary protein; involvement of cholecystokinin. Aquaculture 238, 295-308.

86. Zambonino Infante JL \& Cahu CL (2007) Dietary modulation of some digestive enzymes and metabolic processes in developing marine fish: applications to diet formulation. Aquaculture 268, 98-105.

87. Cahu CL, Zambonino Infante JL \& Barbosa V (2003) Effect of dietary phospholipid level and phospholipid: neutral lipid value on the development of sea bass (Dicentrarchus labrax) larvae fed a compound diet. Br J Nutr 90, 21-28.

88. Ma HM, Cahu C, Zambonino J, et al. (2005) Activities of selected digestive enzymes during larval development of 
large yellow croaker (Pseudosciaena crocea). Aquaculture 245, 239-248.

89. Smith WL, Garavito RM \& DeWitt DL (1996) Prostaglandin endoperoxide $\mathrm{H}$ synthases (cyclooxygenases)-1 and -2 . J Biol Chem 271, 33157-33160.

90. O'Neill GP \& Ford-Hutchinson AW (1993) Expression of mRNA for cyclooxygenase-1 and cyclooxygenase-2 in human tissues. FEBS Lett 330, 157-160.

91. Ishikawa TO, Griffin KJ, Banerjee U, et al. (2007) The zebrafish genome contains two inducible, functional cyclooxygenase-2 genes. Biochem Biophys Res Commun 352, 181-187.

92. Havird JC, Miyamoto MM, Choe KP, et al. (2008) Gene duplications and losses within the cyclooxygenase family of teleosts and other chordates. Mol Biol Evol 25, 2349-2359.

93. Qu W, Bradbury JA \& Tsao CC (2001) Cytochrome P450 CYP2J9, a new mouse arachidonic acid $\omega-1$ hydroxylase predominately expressed in brain. J Biol Chem 276, 25467-25479.

94. Crofford LJ (1997) COX-1 and COX-2 tissue expression: implications and predictions. J Rheumatol Suppl 49, 15-19.
95. Badawi AF, El-Sohemy A, Stephen LL, et al. (1998) The effect of dietary $n-3$ and $n-6$ polyunsaturated fatty acids on the expression of cyclooxygenase 1 and 2 and levels of p21ras in rat mammary glands. Carcinogenesis 19, 905-910.

96. Fisslthaler B, Popp R, Michaelis UR, et al. (2001) Cyclic stretch enhances the expression and activity of coronary endothelium-derived hyperpolarizing factor synthase. Hypertension 38, 1427-1432.

97. Bauersachs J, Christ M, Ertl G, et al. (2002) Cytochrome P450 $2 \mathrm{C}$ expression and EDHF-mediated relaxation in porcine coronary arteries is increased by cortisol. Cardiovasc Res 54, 669-675.

98. Newberry RD, Stenson WF \& Lorenz RG (1999) Cyclooxygenase-2-dependent arachidonic acid metabolites are essential modulators of the intestinal immune response to dietary antigen. Nat Med 5, 900-906.

99. Cortese JF, Spannhake EW, Eisinger W, et al. (1995) The 5-lipoxygenase pathway in cultured human intestinal epithelial cells. Prostaglandins 49, 155-166. 